\title{
Birth-Related Up-Regulation of mRNA Encoding Tyrosine Hydroxylase, Dopamine $\beta$-Hydroxylase, Neuropeptide Tyrosine, and Prepro-Enkephalin in Rat Adrenal Medulla Is Dependent on Postnatal Oxygenation
}

\author{
HANS HOLGERT, JEAN-MARC PEQUIGNOT, HUGO LAGERCRANTZ, AND TOMAS HÖKFELT
}

Department Woman and Child Health, Karolinska Hospital, S-171 76 Stockholm, Sweden [H.H., H.L.]; Department Neuroscience, Karolinska Institute, S-171 77 Stockholm, Sweden [H.H., H.L., T.H.]; and URA CNRS 1195, Facultè de Medicine Grange Blanche, Lyon, France [J.-M. P.]

\section{ABSTRACT}

The transynaptic splanchnic regulation of the adrenal medulla is not functional in the newborn rat. Thus, synthesis and release of adrenal catecholamines and peptides are assumed to be regulated by nonneuronal mechanisms at this stage. In a previous study we reported 4-5-fold increases in the levels of mRNA encoding tyrosine hydroxylase (TH), dopamine $\beta$-hydroxylase $(\mathrm{DBH})$, and neuropeptide tyrosine (NPY) in the rat adrenal medulla immediately after birth. In the present in situ hybridization study the importance of postnatal oxygenation for the birthrelated increase in expression of these mRNA, and of preproenkephalin (ENK) mRNA was investigated in rat pups. We report here that maternal hypoxia $\left(11-13 \% \mathrm{O}_{2}\right)$ leads to $2-3$-fold increases $(p<0.01)$ in fetal adrenal TH, DBH, and NPY mRNA levels on the day before birth. These mRNA then further increased 1.5-2-fold $(p<0.01) 12 \mathrm{~h}$ after birth in room air. Only ENK mRNA levels increased (5-fold; $p<0.01$ ) when pups were born in $11-13 \% \mathrm{O}_{2}$; however, still less $(p<0.01)$ than after birth in room air when it increased nine times $(p<0.01)$. Thus, the birth-related increases in TH, DBH, NPY, and ENK mRNA levels in the rat adrenal medulla are dependent on postnatal oxygenation. (Pediatr Res 37: 701-706, 1995)

\section{Abbreviations}

DBH, dopamine $\beta$-hydroxylase

E21, embryologic d 21

ENK, enkephalin

hypo, hypoxic

norm, normoxic

NPY, neuropeptide tyrosine

PC12, pheochromocytoma cells 12

SSC, sodium-cloride sodium citrate

TH, tyrosine hydroxylase
Synthesis and release of adrenal catecholamines (1) and peptides $(2,3)$ are mainly regulated transynaptically by the splanchnic nerve in adult animals (4). However, this regulation does not appear to be fully mature until $10-12 \mathrm{~d}$ of age in the rat $(5,6)$. Still, catecholamines can be released due to stressful stimuli such as hypoxia (7). Furthermore, the levels of mRNA for TH, DBH, and NPY increase 4-5-fold, 12 and $24 \mathrm{~h}$ after birth (8), probably to replace catecholamines and NPY released at birth $(9,10)$. Thus, a nonneuronal mechanism(s) regulating synthesis and release of catecholamines and peptides seems to be present. One such nonneuronal factor of interest, especially for the up-regulation of various mRNA in the rat adrenal

Received July 28, 1994; accepted December 20, 1994

Correspondence: Dr. Hans Holgert, Department Woman and Child Health (Barnkliniken), Karolinska Hospital, S-171 76 Stockholm, Sweden.

Supported by the Stiftelsen Sven Jerrings Fond, Sällskapet Barnavård, and the Swedish Medical Research Council (2887 and 5234). medulla at birth (8), is the role of postnatal oxygenation. Access to oxygen postnatally may be a limiting factor for enzyme activity and protein synthesis, including expression of mRNA. In fact, recently several genes have been shown to be regulated by oxygen levels, e.g. the erythropoietin gene (1113). Also TH seem to be regulated by oxygen levels in the carotid body but not in the adrenal medulla of adult rats (14).

In addition to catecholamines several peptides, e.g. ENK and NPY, are present in chromaffin cells in the rat adrenal medulla (15-18), and several peptides are abundant before the establishment of a "functional" splanchnic innervation (6). The functional role of such adrenal peptides has not yet been clarified. However, ENK has been suggested to exert an inhibitory modulation of the catecholamine release from the adrenal medulla in early life (19), and the opiate antagonist naloxone increases the surge of catecholamines at birth in fetal sheep (20). Thus, ENK might act as an autoregulating factor of 
adrenal catecholamine release (and synthesis) before the onset of a functional innervation.

The present study was undertaken to further study the regulation of expression of mRNA encoding $\mathrm{TH}, \mathrm{DBH}, \mathrm{NPY}$, and ENK in the rat adrenal medulla at birth, i.e. well before a mature transynaptic regulation has been established. Focus is on the role of postnatal oxygenation, and in situ hybridization histochemistry with synthetic oligonucleotides was used.

\section{METHODS}

Animal keeping and hypoxic exposure. Five pregnant Sprague-Dawley rats (IFFA CREDO, L'Arbresle, France) were used. At d 17-18 of pregnancy four rats were placed in a Plexiglas chamber with an individual space for each rat. One day later the oxygen levels were reduced to $11-13 \% \mathrm{O}_{2}$ and kept at this level throughout the experiment. The $\mathrm{CO}_{2}$ levels were never allowed to exceed $0.1 \%$, and the temperature in the chamber varied between 24.2 and $26.1^{\circ} \mathrm{C}$. All litters were born in the hypoxic environment 2-3 d after the gas switch, but were then subject to different postnatal milieus before sacrifice and dissection (see Fig. 1 for explanation). The pups were kept with their mothers throughout the experiment. Before cesarean section the mothers were anesthetized with Mebumal $(40 \mathrm{mg} / \mathrm{kg}$, i.p.). Pups of all groups were killed by a hard blow on their head. The adrenals were then rapidly dissected out, mounted, and frozen in $0.9 \%$ sterile saline on dry ice, sectioned at $14 \mu \mathrm{m}$ in a cryostat (Microm, Heidelberg, Germany), and thawed onto ProbeOn microscope slides (Fisher Scientific, Pittsburgh, PA).

Probes and probe labeling procedure. Four synthetic oligonucleotides complementary to, respectively, nucleotides 1441-1488 of rat TH mRNA (21), nucleotides 91-136 of rat DBH mRNA (22), nucleotides 1671-1714 of rat NPY mRNA (23), and nucleotides 322-361 of rat prepro-ENK mRNA (24) were used. The oligonucleotides were labeled with $\alpha-{ }^{35}$ S-dATP (DuPont NEN, Boston, MA) at the $3^{\prime}$-end using terminal deoxynucleotidyltransferase (Amersham Corp., Amersham, UK) and purified through Nensorb 20 columns (Du Pont NEN).

Hybridization procedure. Hybridization of the nonfixed tissues was performed at $42^{\circ} \mathrm{C}$ for $16 \mathrm{~h}$, essentially as previously described (25). In brief, hybridization was performed in a solution containing $50 \%$ formamide (J. T. Baker Chemicals B.V., Deventer, Holland $), 4 \times \mathrm{SSC}(1 \times \mathrm{SSC}=0.15 \mathrm{M} \mathrm{NaCl}$, $0.015 \mathrm{M}$ sodium citrate), $1 \times$ Denhardt's solution $(0.02 \%$ each of bovine serum albumin, Sigma Chemical Co., St. Louis, MO;
Ficoll, Pharmacia, Uppsala, Sweden; polyvinylpyrrolidone, Sigma Chemical Co.), $0.02 \mathrm{M}$ sodium phosphate ( $\mathrm{pH} 7.0$ ), $10 \%$ dextran sulfate (pH 7.0) (Pharmacia), 1\% Sarkosyl (Nlauroyl-sarcosine, Sigma Chemical Co.), $500 \mathrm{mg} / \mathrm{mL}$ salmon testis deoxynucleic acid (Sigma Chemical Co.) and $200 \mathrm{mM}$ dithiothreitol (LKB, Stockholm, Sweden). After hybridization the sections were rinsed in $\mathrm{SSC}$ at $55^{\circ} \mathrm{C}$ for $60 \mathrm{~min}$ with four changes of SSC and then brought to room temperature in SSC. Sections were then briefly transferred through distilled water, $60 \%$ and $95 \%$ ethanol, air-dried, covered with Hyperfilm$\beta \max$ autoradiography film (Amersham) and exposed at $-20^{\circ} \mathrm{C}$ for $35 \mathrm{~h}(\mathrm{DBH})$ or $100 \mathrm{~h}$ (TH, NPY, ENK). Subsequently, the sections were dipped in liquid photoemulsion (NTB2; Eastman Kodak, Rochester, NY) and exposed for 7-14 d. After the exposure the unstained sections were analyzed in a Nikon Microphot-FX microscope, under side-light conditions (Darklite, Micro Video Instruments Inc., Avon, MA) and after staining with cresyl violet under brightfield conditions.

Quantitative autoradiography. Computerized quantification of relative levels of mRNA was made possible by hybridizing tissues from the various groups together, and by using ${ }^{14} \mathrm{C}$-labeled plastic standards (Amersham) and Hyperfilm $\beta$-max (Amersham) (see Ref. 26). Each image was digitized with 256 gray levels for each picture element and was adjusted for possible artifacts in the illumination or optical pathway. Gray levels for each ${ }^{14} \mathrm{C}$-labeled plastic standard were determined and used in a third degree polynomial approximation to construct a gray level (256 levels) to activity transfer function. The boarders of the measuring fields, i.e. of each individual adrenal medulla, were interactively defined, and the average activities in the tissues were calculated using Wingz software (Microsoft Corporation, Redmond, WA). The E21 $1^{\text {hypo }}$ level of respective mRNA was used as an internal standard and set to $100 \%$. Analysis of variance was used for statistical analysis, and $p<0.05$ was regarded as significant. Eight animals were used in all groups except for the E21 $1^{\text {norm }}$ group which contained four animals.

Ethical considerations. The experiments have been approved by the local ethical committee (Stockholms norra djurförsöksetiska nämnd; Dnr N178/90 and N159/93).

\section{RESULTS}

The pups and the mothers coped well with the hypoxic environment, e.g. they were moving around, and the pups were sucking. Specific signals for TH (Figs. $2 a$ and $c ; 3 a-c$ ), DBH,

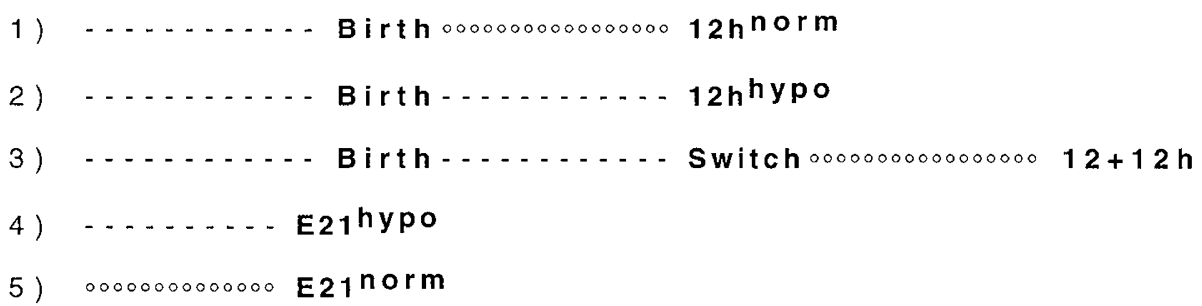

Figure 1. Schematic illustration over the experimental protocol. Four pregnant rats $(l-4)$ were placed in a hypoxic $\left(----; 11-13 \%\right.$ O $\mathrm{O}_{2}$ chamber after $17-18$ $\mathrm{d}$ of pregnancy and left there until delivery. When born, the litters were subjected to different oxygen milieus. One litter ( 1 ) was immediately removed to room air $\left({ }^{\circ 000} ; \approx 21 \% \mathrm{O}_{2}\right)$ and allowed to remain there for $12 \mathrm{~h}\left(12-\mathrm{h}^{\text {norm }}\right)$; a second litter $(2)$ was reared in the hypoxic milieu for $12 \mathrm{~h}$ after birth $\left(12-\mathrm{h}^{\text {hypo }}\right)$; and a third litter (3) was first reared in the hypoxic milieu for $12 \mathrm{~h}$ and then allowed to breath room air for $12 \mathrm{~h}(12+12 \mathrm{~h}$ ). The litters of one hypoxic (4) and one normoxic (5) mother were delivered by cesarean section on embryologic d 21 (E21 $1^{\text {hypo }}$ and E21 ${ }^{\text {norm }}$, respectively). 

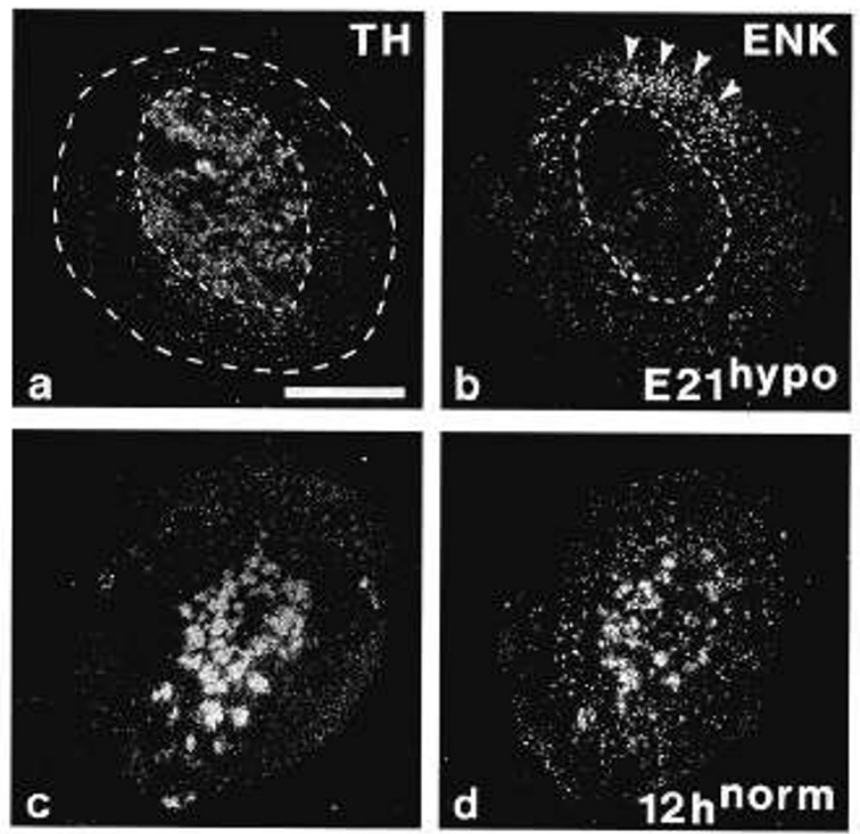

Figure 2. Film autoradiographs of $14-\mu \mathrm{m}$ thick adjacent sections of adrenal medullae of $\mathrm{E} 21^{\text {hypo }}(a, b)$ and $12-\mathrm{h}^{\text {norm }}(c, d)$ rats hybridized in situ with synthetic oligonucleotide probes complementary to TH $(a, c)$ and $\operatorname{ENK}(b, d)$ mRNA and exposed to liquid photoemulsion. The outer boarders of the adrenal cortex $(a)$ and of the E21 $1^{\text {hypo }}$ medulla $(a, b)$ are indicated by the dotted lines. Note the dramatic increase in ENK mRNA levels from the E21 $1^{\text {hypo }}$ to the 12 $\mathrm{h}^{\text {norm }}$ stage. Arrowheads in $\mathrm{b}$ point to unspecific signal in cortex due to refraction by lipid granules. $\mathrm{c}$ is slightly retouched. Bar indicates $0.5 \mathrm{~mm}$.

NPY, and ENK (Figs. $2 b$ and $d ; 3 d-f$ ) mRNA were found over the adrenal medullae (Fig. 2) and at higher magnification over groups of chromaffin cells (Fig. 3). The levels of mRNA encoding $\mathrm{TH}, \mathrm{DBH}$, and NPY were significantly $(p<0.01)$ higher in the hypoxic fetuses (E21 ${ }^{\text {hypo }}$ ) compared with the levels in the normoxic fetuses (E21 ${ }^{\text {norm }}$ ) (Table 1; Fig. 4). The levels of ENK mRNA were not different in the E21 ${ }^{\text {norm }}$ and the E21 ${ }^{\text {hypo }}$ groups (Table 1; Fig. 4).

The levels of TH (Figs. $2 a$ and $c ; 3 a$ and $b$ ), DBH, NPY, and ENK (Figs. $2 b$ and $d ; 3 e$ and $f$ ) mRNA increased significantly $(p<0.01)$ within $12 \mathrm{~h}$ after birth, when the rat pups were born into room air, compared with the levels in adrenals from the E21 ${ }^{\text {hypo }}$ rats (see Table 1; Fig. 4). ENK mRNA levels increased 5 -fold when pups were born in $11-13 \% \mathrm{O}_{2}(p<0.01$; Table 1; Figs. $3 d$ and $g$; 4), whereas the TH (Table 1; Fig. $3 a$ and $c$ ) and DBH mRNA levels decreased $(p<0.05)$, and the NPY mRNA levels were unchanged (Table 1; Fig. 4). Only the TH mRNA levels increased ( $p<0.05 ; 12 \mathrm{~h}^{\text {hypo }}$ versus $12+12 \mathrm{~h}$ ) when pups were born and reared for $12 \mathrm{~h}$ in $11-13 \% \mathrm{O}_{2}$ and then allowed to breath room air for $12 \mathrm{~h}$. The levels of all four mRNA were significantly $(p<0.05-0.01)$ lower in the $12^{\text {hypo }}$ and $12+12 \mathrm{~h}$ groups compared with the levels of the respective mRNA in the $12^{\text {norm }}$ group (Table 1; Fig. 4).

\section{DISCUSSION}

In the present study relative changes in mRNA levels for enzymes and peptides have been quantitatively analyzed in the rat adrenal medulla using ${ }^{35} \mathrm{~S}$-labeled synthetic oligonucleotides and in situ hybridization combined with ${ }^{14} \mathrm{C}$-labeled plastic standards and Hyperfilm $\beta$-max (26). Comparison of the different groups was made possible by hybridizing tissues from all groups together on the same slide and by concomitant exposure of both the tissues and the standards. The present results confirm our previous findings (8) that expression of mRNA encoding TH, DBH, and NPY, as well as ENK mRNA is markedly up-regulated at birth in the rat adrenal medulla. However, and more importantly, they suggest that an adequate and concomitant postnatal oxygenation is crucial for this upregulation. In addition, $\mathrm{TH}, \mathrm{DBH}$, and NPY mRNA levels were found to be partially up-regulated in utero when the mothers were exposed to hypoxia.

The regulation of TH, DBH, NPY, and ENK mRNA expression before and immediately after birth is likely to be mediated by a nonneuronal mechanism(s) $(5,6)$, as suggested earlier (8). The finding that $\mathrm{TH}, \mathrm{DBH}$, and NPY mRNA levels were increased in the E21 hypo group, compared with the E21 ${ }^{\text {norm }}$ group (Table 1; Fig. 4), indicates that adrenal catecholamine
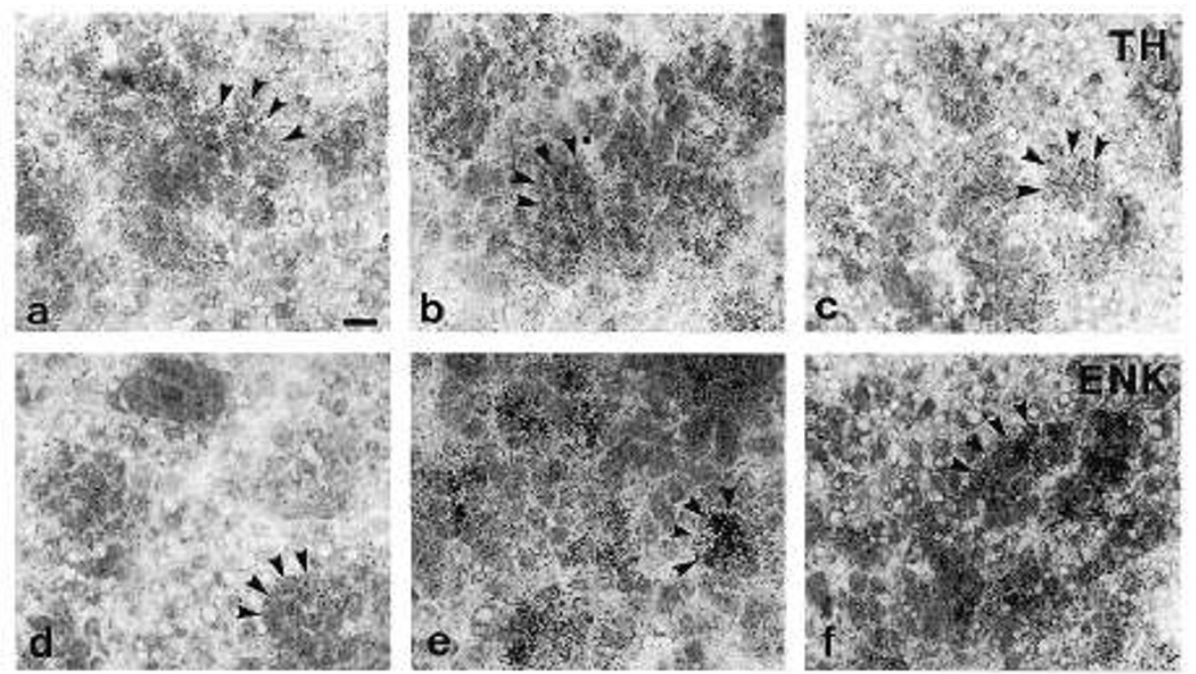

Figure 3. Film autoradiographs of $14-\mu \mathrm{m}$ thick adjacent sections of adrenal medullae of E21 ${ }^{\text {hypo }}(a, d), 12$-horm $(b, e)$, and 12 -h ${ }^{\text {hypo }}(c, f)$ rats hybridized in situ with synthetic oligonucleotide probes complementary to TH $(a-c)$ and ENK $(d-f)$ mRNA and exposed to liquid photoemulsion, stained with toluidine blue, and photographed under brightfield light. Specific signals for TH and ENK mRNA are indicated (arrowheads) over some chromaffin cells. Bar indicates $50 \mu \mathrm{m}$. 
Table 1. Relative levels of $T H, D B H, N P Y$, and ENK mRNAs in the adrenal medulla of fetal and newborn rats

\begin{tabular}{|c|c|c|c|c|c|}
\hline & $\mathrm{E} 21^{\text {norm }}$ & E21 hypo & $12-\mathrm{h}^{\text {norm }}$ & $12-h^{\text {hypo }}$ & $12+12-h$ \\
\hline $\mathrm{TH}$ & $35.1 \pm 2.9$ & $100 \pm 19.3$ & $165.0 \pm 28.0$ & $59.1 \pm 11.6$ & $86.4 \pm 19.1$ \\
\hline $\mathrm{DBH}$ & $58.1 \pm 5.1$ & $100 \pm 17.6$ & $140.9 \pm 31.7$ & $64.7 \pm 7.9$ & $77.0 \pm 15.8$ \\
\hline NPY & $50.4 \pm 5.0$ & $100 \pm 23.3$ & $178.5 \pm 40.7$ & $103.3 \pm 17.4$ & $125.6 \pm 30.0$ \\
\hline ENK & $125.7 \pm 14.2$ & $100 \pm 30.9$ & $984.2 \pm 275.8$ & $516.0 \pm 73.0$ & $463.9 \pm 77.0$ \\
\hline
\end{tabular}

Levels of TH, DBH, NPY, and ENK mRNAs in adrenal medullae of rat pups of the E21 ${ }^{\text {norm }}, 12-\mathrm{h}^{\text {norm }}, 12$-h ${ }^{\text {hypo }}$, and $12+12$-h groups relative their levels in $\mathrm{E} 21^{\text {hypo }}$ rat pups, which were set to $100 \%$ (see Fig. 1 for explanation). Levels are given as mean \pm SD.
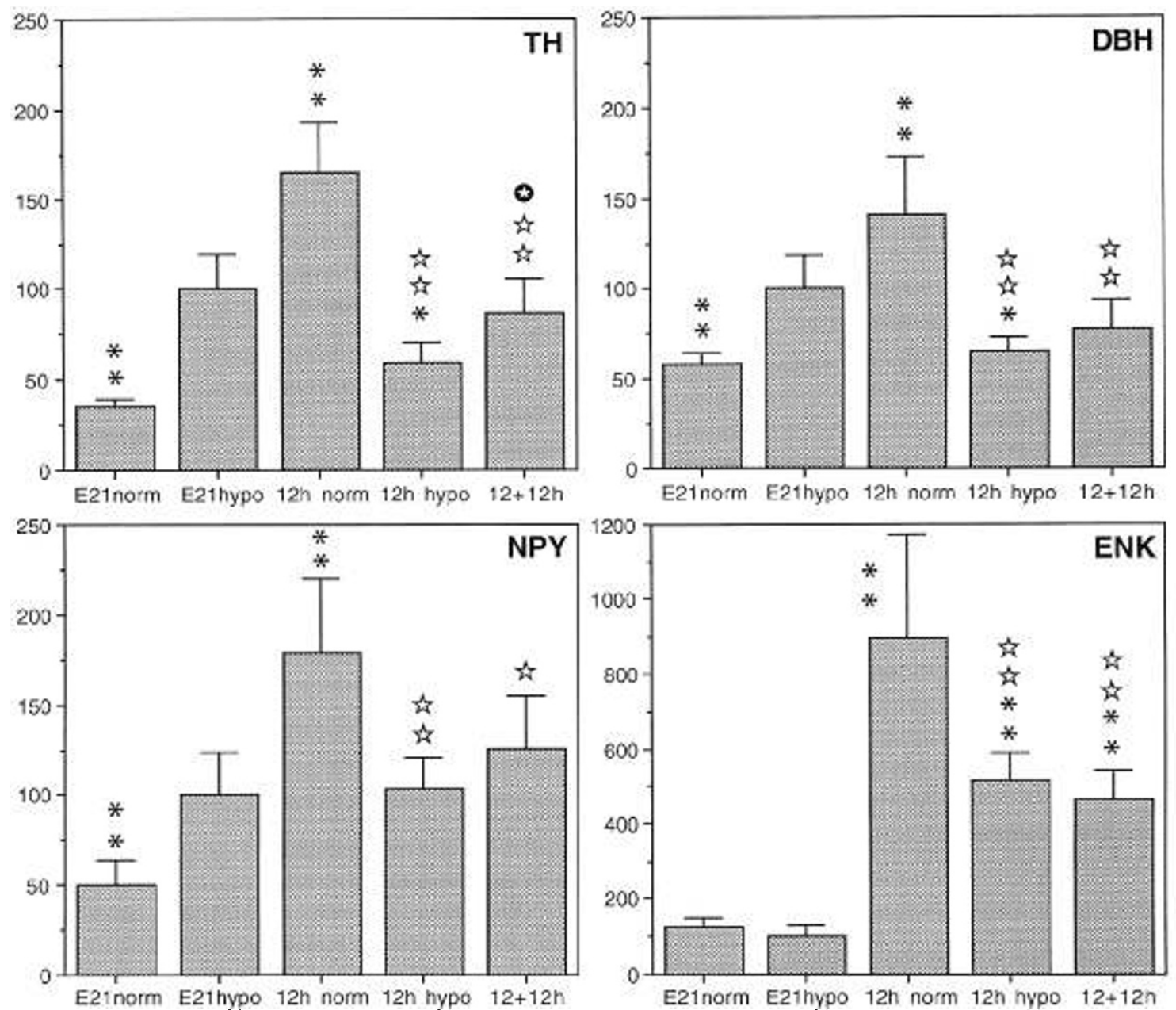

Figure 4. Levels of TH, DBH, NPY, and ENK mRNA in adrenal medullae of the E21 ${ }^{\text {norm }}, 12-\mathrm{h}^{\text {norm }}, 12-\mathrm{h}^{\text {hypo }}$, and $12+12-\mathrm{h}$ groups relative to their respective level in the E21 $1^{\text {hypo }}$ group, which was set to $100 \%$. Mean values are shown, and SD are indicated by the error bars. Significance compared with E21 ${ }^{\text {hypo }}$ rats is indicated by stars $\left(^{*}=p<0.05\right.$ and ${ }^{* *}=p<0.01$ ), and between $12-\mathrm{h}^{\text {norm }}$ levels by open stars. The significant difference in TH mRNA levels between the $12-h^{\text {hypo }}$ and the $12+12$-h groups is indicated by an open star in a black circle. All other comparisons were not significant $(p>0.05)$. Analysis of variance was used for statistical analysis.

and peptide synthesis can be up-regulated already in utero, in this case induced by maternal hypoxia. This corroborates earlier findings of increased catecholamine levels in the hypoxic fetal sheep $(27,28)$, an increase that in the sheep could be mediated both by hormonal $(27,29,30)$ and neuronal (28) inffuences. In our situation neuronal regulation is unlikely (5); however, the relative long term $(2-3 \mathrm{~d})$ prenatal hypoxia may induce elevation also of maternal corticosteroid levels. These hormones can, in contrast to adrenocorticotrophic hormone, pass the fetoplacental barrier, whereby they may affect synthesis of adrenal catecholamines in the fetus. Moreover, glucocorticoids enhance the selective effect of nerve growth factor on induction of TH and DBH (31), mainly by increasing enzyme synthesis (31). Thus, interaction between corticosteroids and nerve growth factor may be one mechanism explaining the up-regulation of enzyme synthesis in the E2 $1^{\text {hypo }}$ group. Interestingly, the levels of ENK mRNA were not affected by fetal hypoxia (Table 1; Fig. 4). The low levels of ENK mRNA in the E21 groups corroborate the view that circulating ENK does not originate from the adrenal in fetal life (32).

Seidler and Slotkin (7) found evidence that hypoxia induces release of adrenal catecholamines in the immature rat, presumably by a direct nonneuronal mechanism. It is possible that intermittent asphyxia during the delivery process induces release of catecholamines $(9,10)$ and of adrenal peptides. It may as well induce a compensatory increase in synthesis of cat- 
echolamines, enzymes, and peptides, as indicated by the increased levels of TH, DBH, NPY, and ENK mRNA after normal birth. Synthesis of catecholamines may also be stimulated via feedback mechanisms secondary to a possible depletion of catecholamines at birth $(8-10)$.

The preganglionic innervation of the rat adrenal medulla is not fully mature until $10-12 \mathrm{~d}$ of age, as revealed by functional tests (5) and by analysis of the presence of ENK- and acetylcholinesterase-like immunoreactivities (6). However, the sensory innervation develops much earlier (6). It may be speculated that transmitter release from sensory nerve endings in the adrenal may contribute to the up-regulation of adrenal enzyme and peptide synthesis at birth (33).

However, notified should be that catecholamine synthesis is primarily regulated by phosphorylation of the TH enzyme (34). The rate of catecholamine synthesis may therefore be high in spite of unchanged enzyme synthesis. In fact, TH enzyme activity, but not TH mRNA levels, is increased by hypoxia in the adult rat adrenal medulla (14).

ENK mRNA levels were found to increase 9-fold $12 \mathrm{~h}$ after birth in room air and 5-fold when pups were born in 11-13\% $\mathrm{O}_{2}$. The marked relative increases in ENK mRNA levels after birth can partly be explained by the very low levels of ENK mRNA detected in the fetal adrenal medulla (Table 1; Figs. $2 b$ anf $d ; 3 d-f ; 4)$. Moreover, ENK mRNA levels were five times higher (compared with the $\mathrm{E} 21^{\text {hypo }}$ rats) in pups exposed to room air for $12 \mathrm{~h}$ after birth in 11-13\% $\mathrm{O}_{2}$ (Table 1; Figs. $2 b$ and $d ; 3 d-f ; 4)$. Taken together, these results indicate that expression of ENK mRNA is regulated in a different way compared with TH, DBH, and NPY mRNA, in spite of the fact that ENK and catecholamines are co-stored and co-released in the adrenal medulla $(15,16)$. However, postnatal oxygenation seems to be of importance also for ENK mRNA expression, because its levels were lower $(p<0.01)$ in the $12-\mathrm{h}^{\text {hypo }}$ group compared with in the $12-h^{\text {norm }}$.

Previous studies have shown that ENK inhibits the release of catecholamines in the immature adrenal gland $(19,20)$. The high postnatal levels of ENK mRNA may relate to a surge of adrenal ENK at birth, e.g. stress induced (35-37). The function of this ENK may be to ensure that release and synthesis of catecholamines are not overstimulated at birth $(19,20)$. It may also be speculated that adrenal ENK has an endogenous analgesic effect in the fetus during the parturition process and during the immediate period thereafter. In fact, ENK has been suggested to mediate stress-induced analgesia $(38,39)$.

It is known from experiments on rat pups that the turnover of catecholamines in the brain increases within $2 \mathrm{~h}$ after birth, and that this increase is related to air breathing (40), i.e. to the increase in oxygen levels that normally occurs after birth. Oxygen sensitive mechanisms may regulate release (and synthesis) of catecholamines and peptides also in the adrenal. In fact, the levels of TH mRNA in the rat carotid body (14) and in PC12 cells (41) are increased by hypoxia. In PC12 cells this seems to be mediated both by an increased transcription (41) and by stabilization of the mRNA (41) by a cytoplasmatic, mRNA binding protein (42). Although TH mRNA levels do not increase in response to hypoxia in the adult rat adrenal (14), it is tempting to speculate that oxygen might regulate gene expression and/or mRNA stability in the rat adrenal medulla at immature stages. For example, the binding of the nuclear transcription factors Jun and Fos to activator protein-1 sites may be regulated by their redox state (43). Inasmuch as activator protein- 1 sites are found in several genes that are expressed in the adrenal $(44,45)$, this may be one mechanism by which oxygen levels could influence, e.g. TH mRNA expression. Interestingly, oxygen levels increase more than 2 -fold shortly after birth. Thus, oxygen-sensitive mechanisms regulating gene expression, if they exist, have to undergo rapid changes or "switches" after birth. Clearly, if a mechanism sensitive to hypoxia contributes to the up-regulation of $\mathrm{TH}$, DBH, and NPY mRNA levels in the E21 $1^{\text {hypo }}$ rats, then it is either "turned off," replaced, or "over-ridden" by other mechanisms after birth. Finally, access of oxygen postnatally may be a limiting factor for, e.g. mRNA synthesis. The relation between adrenal gene regulation and oxygen levels, and eventual developmental changes in this regard, clearly need further investigation.

The relative birth-related increases in TH, DBH, and NPY mRNA levels shown in the present study are lower than earlier reported (8). This is mainly due to the fact that the levels of these mRNA were already up-regulated in the E21 $1^{\text {hypo }}$ group (see above), which was used as internal reference in the present study, leading to relatively smaller changes at $12 \mathrm{~h}$. However, the levels in the $12-h^{\text {norm }}$ group correspond well to our earlier results when compared with the present levels in the $\mathrm{E} 21^{\mathrm{norm}}$ group $(\mathrm{TH}=470 \%$ versus $512 \%$; $\mathrm{DBH}=242 \%$ versus $370 \%$; $\mathrm{NPY}=354 \%$ versus $253 \%$ ). The remaining discrepancy for $\mathrm{TH}$ and DBH mRNA levels between the two experiments may relate to the fact that the pregnant rats in the present study were reared in $11-13 \% \mathrm{O}_{2}$ (except for the E21 ${ }^{\text {norm }}$ group), whereas all pregnant rat mothers were reared in room air in our previous experiments (8). Additionally, it is known that the environmental temperature influences the increase in catecholamine turnover in the rat brain at birth (46). Although temperature has less effect on adrenal catecholamines in this regard $(40,46)$, it cannot be ruled out that the somewhat smaller relative birthrelated changes in TH and DBH mRNA levels in the present study relate to the circumstance that the pups were born at $26^{\circ} \mathrm{C}$, whereas the room temperature was $22^{\circ} \mathrm{C}$ in the previous experiment. Interestingly, the relative increase in NPY mRNA levels was lower in the previous study, indicating that synthesis of this peptide mRNA is either inhibited in utero due to the asphyxia leading to relatively greater changes, or induced to a higher extent if the fetus is asphyxic before birth. The latter explanation seems to be more likely, because NPY is found at high levels during stressful stimuli such as exercise $(47,48)$ and birth (49).

Our results show that the parturition process per se was not efficient enough to induce the increase in TH, DBH, and NPY mRNA levels (Table 1; Figs. $3 a, c-f ; 4$ ). Moreover, increasing the $\mathrm{O}_{2}$ levels from 11 to $13 \% \mathrm{O}_{2}$ to room air $12 \mathrm{~h}$ after birth did not (DBH, NPY, ENK), or only slightly (TH; $p<0.05$ ) increase the levels of these mRNA in the adrenal medulla, compared with the $12-h^{\text {hypo }}$ rats. Thus, a concomitant postnatal oxygenation seems to be essential for the birth-related increase in expression of the studied mRNA. The present results there- 
fore indicate that the replacement of catecholamines released during the period of birth may be attenuated, if the fetus is not adequately oxygenated at and after birth, because in this case synthesis of TH and DBH enzymes and of NPY may be low. This may lead to a situation where too low levels of catecholamines and NPY could increase the vulnerability of the newborn to new hypoxic challenges $(50,51)$.

\section{CONCLUSION}

The present results indicate that adrenal catecholamine and NPY synthesis are up-regulated in utero by maternal hypoxia. The birth-related increases in TH, DBH, NPY, and ENK mRNA levels seems to be regulated by, and/or dependent on an adequate and concomitant postnatal oxygenation. Thus, postnatal oxygenation may be important for the replacement of adrenal catecholamines released at birth.

Acknowledgments. Dr. Jean-Marie Cottet-Emard, Jacqueline Pequignot, Margarita Diez, Siv Nilsson and Katarina Åhman are acknowledged for their skillful technical assistance.

\section{REFERENCES}

1. Axelrod J 1971 Noradrenaline: fate and control of its synthesis. Science 173:598-606

2. Eiden LE, Giraud P, Dave J, Hotchkiss JA, Affolter H-U 1984 Nicotine receptor stimulation activates both enkephalin release and biosynthesis in adrenal chromaffin cells. Nature 312:661-663

3. Affolter H-U, Giraud P, Hotchkiss AJ, Eiden LE 1984 In: Fraioli A, Isidori A, Mazzeti M (eds) Opiate Peptides in the Periphery. Elsevier, Amsterdam, pp 23-30

4. Thoenen H, Mueller RA, Axelrod J 1969 Trans-synaptic induction of adrenal tyrosine hydroxylase. J Pharmacol Exp Ther 169:249-254

5. Slotkin TA 1986 Development of the sympatoadrenal axis. In: Gootman PM (ed) Developmental Neurobiology of the Autonomic Nervous System. Humana Press, Totowa, NJ, pp. 69-96

6. Holgert H, Dagerlind A, Hökfelt T, Lagercrantz H 1994 Neuronal markers, peptides and enzymes in nerves and chromaffin cells in the rat adrenal medulla during postnatal development. Dev Brain Res 83:35-52

7. Seidler FJ, Slotkin TA 1985 Adrenomedullary function in the neonatal rat: responses to acute hypoxia. J Physiol 358:1-16

8. Holgert $\mathrm{H}$, Schalling M, Hertzberg T, Lagercrantz H, Hökfelt T 1991 Changes in levels of mRNA coding for catecholamine synthesizing enzymes and neuropeptide $Y$ in the adrenal medulla of the newborn rat. J Dev Physiol 16:19- 26

9. Lagercrantz H, Bistoletti P 1977 Catecholamine release in the newborn infant at birth. Pediatr Res 11:889-893

10. Lagercrantz H, Slotkin TA 1986 The "stress" of being born. Sci Am 254:100-107

11. Jelkmann WR, Schmid CW 1992 Erythropoietin: structure, control of production, and function. Physiol Rev 72:449-489

12. Krantz SB 1991 Erythropoietin. Blood 77:419-434

13. Helfman T, Falanga V 1993 Gene expression in low oxygen tension. Am J Med Sci 306:37-41

14. Czyzyk-Krzeska MF, Bayliss DA, Lawson EE, Millhorn DE 1992 Regulation of tyrosine hydroxylase gene expression in the rat carotid body by hypoxia. $\mathrm{J}$ Neurochem 58:1538-1546

15. Schultzberg M, Lundberg JM, Hökfelt T, Terenius L, Brandt J, Elde RP, Goldstein M 1978 Enkephalin-like immunoreactivity in gland cells and terminals of the adrenal medulla. Neuroscience 3:1169-1186

16. Viveros OH, Diliberto EJ, Hazum E, Chang K-J 1979 Opiate-like materials in the adrenal medulla; evidence for storage and secretion with catecholamines. Mol Pharmacol 16:1101-1108

17. Pelto-Huikko M 1985 Immunocytochemical localization of neuropeptides in the rat adrenal medulla. J Electron Microsc Tech 12:364-379

18. Kondo H 1985 Immunohistochemical analysis of the localization of neuropeptides in the adrenal gland. Arch Histol Jpn 48:453-481

19. Chantry CJ, Seidler FJ, Slotkin TA 1982 Non-neurogenic mechanism for reserpineinduced release of catecholamines from the adrenal medulla of neonatal rats: possible modulation by opiate receptors. Neuroscience 3:673- 678

20. Padbury JF, Agata Y, Polk DH, Wang DL, Callegari CC 1987 Neonatal adaptation: naloxone increases the catecholamine surge at birth. Pediatr Res 21:590-593

21. Grima B, Lamouroux A, Blanot F, Faucon-Biguet N, Mallet J 1985 Complete coding sequence of rat tyrosine hydroxylase mRNA. Proc Natl Acad Sci USA 82:617-622

22. McMahon A, Geertman R, Sabban EL 1990 Rat dopamine $\beta$-hydroxylase: Molecular cloning and characterization of the cDNA and regulation of the mRNA by reserpine. J Neurosci Res 25:395-404
23. Larhammar D, Ericsson A, Persson H 1987 Structure and expression of the rat neuropeptide-Y gene. Proc Natl Acad Sci USA 84:2068-2072

24. Howells RD, Kilpatrick DL, Bhatt R, Monaham J-J, Pooniam M, Udenfried S 1984 Molecular cloning and sequence determination of rat preproenkephalin cDNA: Sensitive probe for studying transcriptional changes in rat tissue. Proc Natl Acad Sci USA 81:7651-7655

25. Dagerlind $\AA$, Friberg K, Bean AJ, Hökfelt T 1992 Sensitive mRNA detection using unfixed tissue: combined radioactive and non-radioactive in situ hybridization histochemistry. Histochemistry 98:39-49

26. Miller JA 1991 The calibration of ${ }^{35} \mathrm{~S}$ or ${ }^{32} \mathrm{~S}$ with ${ }^{14} \mathrm{C}$-labeled brain paste or ${ }^{14} \mathrm{C}$-plastic standards for quantitative autoradiography using LKB Ultrofilm or Amersham Hyperfilm. Neurosci Lett 121:211-214

27. Jones CT, Robinson RO 1975 Plasma catecholamines in foetal and adult sheep. J Physiol 248:15-33

28. Cheung CY 1990 Fetal adrenal medulla catecholamine response to hypoxia- direct and neuronal components. Am J Physiol 256:1340-1346

29. Jones CT, Boddy K, Robinson JS, Ratcliffe JG 1977 Developmental changes in the responses of the adrenal glands of foetal sheep to endogenous adrenocorticotrophin, as indicated by hormone responses to hypoxaemia. J Endocrinol 72:279-292

30. Jones CT 1977 The development of some metabolic responses to hypoxia in the foetal sheep. J Physiol 265:743-762

31. Otten U, Schwab M, Gagnon C, Thoenen H 1977 Selective induction of tyrosine hydroxylase and dopamine $\beta$-hydroxylase by nerve growth factor: comparison between adrenal medulla and sympathetic ganglia of adult and newborn rats. Brain Res 133:291-303

32. Simonetta G, Young IR, Coulter CL, Hey NJ, McMillen IC 1993 Fetal adrendalectomy does not affect circulatory enkephalins in the sheep fetus during late gestation. Neuroendocrinology 57:408-415

33. Livett BG, Marley PD, Wan DDC, Xin-Fu Z 1990 Peptide regulation of adrenal medullary functions. J Neural Transm Suppl 29:77-89

34. Zigmond RE, Schwartzschild MA, Rittenhouse AR 1989 Acute regulation of tyrosine hydroxylase by nerve activity and by its neurotransmitters via phosphorylation. Annu Rev Neurosci 12:415-461

35. Espinoza M, Riquelme R, Germain AM, Tevah J, Parer JT, Llanos AJ 1989 Role of endogenous opioids in the cardiovascular responses to asphyxia in the fetal sheep. Am J Physiol 256:1063-1068

36. Kanamatsu T, Unsworth CD, Diliberto Jr EJ, Viveros OH, Hong JS 1986 Reflex splanchnic nerve stimulation increases levels of proenkephalin A mRNA and proenkephalin A-related peptides in the rat adrenal gland. Proc Natl Acad Sci USA 83:9245-9249

37. Viveros OH, Diliberto Jr EJ, Hong JH, Kizer JS, Unsworth CD, Kanamatsu T 1987 The regulation of enkephalin levels in adrenomedullary cells and its relation to chromaffin vesicle biogenesis and functional plasticity. Ann NY Acad Sci 493:324-341

38. Madden J, Akil H, Patrick RL, Barchas JD 1977 Stress-induced parallel changes in central opioid levels and toma. Proc Natl Acad Sci USA 76:4079-4083

39. Lewis JW, Tordoff MG, Sherman JE, Liebeskind JC 1981 Role of the adrenal medulla in opioid stress analgesia. Soc Neurosci Abstr 7:735

40. Lagercrantz H, Pequignot J, Pequignot J-M, Peyrin L 1992 The first breath of ait stimulate noradrenaline turnover in the brain of the newborn rat. Acta Physiol Scand $144: 433-438$

41. Czyzyk-Krzeska MF, Bayliss DA, Lawson EE, Millhorn DE 1994 Hypoxia increases rate of transcription and stability of tyrosine hydroxylase mRNA in pheochromocytoma (PC12) cells. J Biol Chem 269:760-764

42. Czyzyk-Krzeska MF, Dominski Z, Kole R, Millhorn DE 1994 Hypoxia stimulates binding of a cytoplasmatic protein to a pyrimidine-rich sequence in the $3^{\prime}$ untranslated region of rat tyrosine hydroxylase mRNA. J Biol Chem 269:4940 -4945

43. Abate C, Patel L, Rauscher F, Curran T 1990 Redox regulation of fos and jun DNA binding activity in vitro. Science 249:457-461

44. Stachowiak M, Goc A 1992 Regulation of gene expression in catecholamine and opioid synthesis in sympatoadrenal system-nuclear mechanisms and second messenger system, In: Holle et al. (eds) Advances in the Innervation of the Gastrointestinal Tract. Elsevier Science Publisher BV, London, pp 251-263

45. Icard-Liepkalns C, Biquet NF, Vyas S, Robert JJ, Sassone-Corsi P, Mallet J 1992 AP-1 complex and c-fos transcription are involved in TPA provoked and transsynaptic inductions of the tyrosine hydroxylase gene: insights into long-term regulatory mechanisms. J Neurosci Res 32:290-298

46. Girard JR, Zeghal N 1975 Adrenal catecholamines content in fetal and newborn rats. Biol Neonate 26:205-13

47. Lundberg JM, Martinsson A, Hemsen A. Theodorsson-Norheim E, Svedenhag J, Ekblom B, Hjelmdahl P 1985 Co-release of neuropeptide Y and catecholamines during physical exercise in man. Biochem Biophys Res Commun 133:30-36

48. Pernow J, Lundberg JM, Kaijser L, Hjelmdahl P, Theodorsson-Norheim E, Martinsson A, Pernow B 1986 Plasma neuropeptide Y-like immunoreactivity and catecholamines during various degree of sympathetic activation in man. Clin Physiol 6:562-578

49. Lundberg JM, Hemsen A, Fried G, Theodorsson-Norheim E, Lagercrantz H 1986 Co-release of neuropeptide Y (NPY)-like immunoactivity and catecholamines in newborn infants. Acta Physiol Scand 126:471-473

50. Jones CT 1980 Circulating catecholamines in the fetus, their origin, actions and significance. In: Parvez H, Parvez S (eds) Biogenic Amines in Development. Elsevier/ North-Holland Biomedicakl Press, Amsterdam, pp 63-68

51. Padbury JF, Martinez MA 1988 Sympathoadrenal system activity at birth: Integration of postnatal adaption. Semin Perinatol 12:163-172 